\title{
Modeling the influence of factors on the level of environmental safety
}

\author{
Serhii Pobihun ${ }^{1, *}$, Nataliia Havadzyn ${ }^{2}$, Ivanna Melnychuk ${ }^{3}$, Oksana Savko ${ }^{3}$, and Valeria Mirela Brezoczki ${ }^{4}$ \\ ${ }^{1}$ State Institution "Ivano-Frankivsk National Technical University of Oil and Gas", Institute of Economics and Management, \\ Department of Entrepreneurship and Marketing, 15 Karpatska str., Ivano-Frankivsk, 79019, Ukraine \\ ${ }^{2}$ Institution of higher education «King Danylo University» Department of Management and Administration, 35 Konoval'tsia Yevhena \\ str., Ivano-Frankivsk, 79018, Ukraine \\ ${ }^{3}$ State Institution "Ivano-Frankivsk National Technical University of Oil and Gas", Institute of Economics and Management, \\ Department of Applied Economics, 15 Karpatska str., Ivano-Frankivsk, 79019, Ukraine \\ ${ }^{4}$ North University Centre at Baia Mare, Technical University of Cluj-Napoca, Faculty of Engineering, 62 V. Babes St., 430083 Baia \\ Mare, Romania
}

\begin{abstract}
There has been established in the article the correlation and regression relationship between the factors of the country's development and the level of environmental safety on the basis of identifying the patterns of certain factors sets influencing the volume of harmful emissions into the atmosphere. On the basis of modeling, there has been carried out the analysis of individual groups of factors influencing the volumes of harmful emissions in the countries selected for the study. The nature and degree of influence of the selected factors on the resulting indicators (volumes of harmful emissions) have been determined. It has been found that the number of these factors is significantly higher in France than in Ukraine. This is due to both the political and economic situation in the country. The level of energy efficient technologies implementation and environmental restructuring of business entities are no less significant. The ranking of factors has been carried out based on the value of the correlation coefficient within a separate group and each country. There are also highlighted differences in the research results and their reasons.
\end{abstract}

\section{Introduction}

In today's world, among the dominant problems, there are environmental ones associated with climate change as they threaten the further development of mankind. The countries participating in the United Nations Framework Convention on Climate Change (1992) have assumed international obligations defined in the Kyoto Protocol (1997) and the Paris Agreement (2015) regarding the reduction of greenhouse gas emissions. This necessitates states with different levels of development to form and implement an effective environmental policy, which will reduce anthropogenic influence and stimulate the development of a "green" economy.

Researchers often focus on identifying and establishing the nature and types of relationships between various phenomena and processes occurring in society (for example, the level of economic development, urbanization, the increase in the use of alternative and traditional types of energy, research, investment and innovation activities) and their influence on environment. For example, to analyze the relationship between emissions, natural resources, revenues and renewable energy in the BRICS countries, there has been applied the AMG method [1]. Natural resources were used as a control variable that showed the relationship between revenues and emissions in the EU-5 countries [2]. The relationship between income, energy consumption and carbon emissions in the United States was studied by [3].

The studies of countries with different income levels were conducted by [4]. The results have shown that energy consumption per capita is the main cause of carbon dioxide emissions. Studies $[5,6]$ have shown that green innovation is the main factor affecting carbon emissions.

There are proposed a modern information and analytical system for monitoring atmospheric air pollution and considered the features of the air quality index in [7, $8,9,10]$. A schematic diagram of the structural organization and relationships between the subjects of environmental monitoring has been developed in [11]. New forms of data presentation on monitoring technogenic loads and risks, reflecting the dynamics of ecological situation in the space of informational features, were proposed in [12].

A prototype of a monitoring system is presented to solve monitoring problems $[13,14]$. There are combined methods that enable us to predict the influence of technogenic activities on human health and are an effective complex of environmental monitoring studies in [15]. There are presented the developed mathematical models that allow predicting atmospheric pollution and are an effective tool for supporting decision-making on the problems of environmental safety of the atmosphere in [16].

\footnotetext{
* Corresponding author: pobigunserg@gmail.com
} 
The risks to public health associated with air pollution have been analyzed and evaluated in [8, 17, 18]. Mathematical models have been developed to reduce the spread of pollutants in the atmosphere $[19,20]$.

A significant influence on air pollution is carried out by the quality of the fuel; the study of the fuel quality management system, the environmental and economic analysis of the developed system is made in [21, 22]. New mathematical tools have been developed in [23, 24, 25] to determine the distribution in space and time of the technogenic load on the atmospheric air from gas wells. The issues of modeling the dispersion of the atmosphere taking into account the mathematical modeling of the emissions formation are shown in [26] and ways of automating the process of scenarios development modeling are highlighted in [27].

The results of scientific research on the reduction of pollution by the oil and gas complex that allow avoiding the ingress of harmful substances into the environment are presented in [28]. The species composition and life status of biocenoses located on the territory of the wells are investigated in [29]. The extent of the environment destruction and the decline in biodiversity are investigated in [30].

An approach and recommendations for increasing the level of environmental safety in areas of oil and gas fields' development are offered in [31, 32]. Offers and their implementation to reduce the influence from the activities of oil and gas facilities in the process of wells drilling are presented in the following scientific papers $[33,34,35$, $36,37,38]$.

The influence of renewable energy on sustainable development was studied in $[39,40]$. The main directions of ecological modernization with the use of economic levers to reduce the negative influence on the environment are considered in [41]. The study of functional dependences of factors influencing the amount of waste using the praximetric method, variance and regression analysis was carried out in $[42,43]$. The influence of social and scientific-intellectual factors, namely the relationship between the education quality of employees and results of their work are studied in [44, 45].

\section{Objective and tasks of research}

The aim of the study is to analyze the patterns of social, environmental, economic, scientific and intellectual factors influence on the volume of harmful emissions, such as carbon dioxide, sulfur dioxide and nitrogen oxide, in order to determine possible ways of affecting the level of environmental safety.

To achieve the goal, the following tasks were set:

- to carry out a correlation analysis for assessing the proximity of the relationship and the nature of the factors affecting the level of harmful emissions;

- to analyze the influence of certain factors groups on harmful emissions for countries with developed economies and developing countries;

- to identify priority causes that lead to changes in factors affecting emissions.

\section{Materials and methods}

Statistical data of Enerdata, World Bank, World Statistics, Eurostat, Index Mundi, OECD, Statista, International Energy Agency for 1999-2018 were used as materials for the study, namely the level of harmful emissions in the atmosphere: $\mathrm{CO}_{2}, \mathrm{SO}_{2}, \mathrm{NO}_{\mathrm{x}}$ and such parameters - factors as: energy intensity of GDP, investment level, rent payments, population density, energy consumption, etc. The object of the research is France as a country with a high level of economic development and Ukraine as a country with a low level of economic development.

Correlation analysis was applied to determine the nature and degree of social, economic, scientific and intellectual factors influence on the amount of harmful emissions, such as carbon dioxide, sulfur dioxide and nitrogen oxides. The study has been based on the coefficients of correlation and determination (approximation), linear and nonlinear (quadratic, logarithmic, inverse, power) functions. The value of the correlation coefficient sign allows us to assess the direction of the selected factors influence on the resulting indicators (the number of emissions). The type of function enables us to understand the nature of the influence: if it is a simple linear one, then the increase or decrease in the indicator occurs evenly. If it is a non-linear one, then we get different levels of acceleration or deceleration of the indicator change depending on the factor change.

\section{Results and discussion}

A change to the climate policy was the adoption of the Kyoto Protocol, which has been in effect since 2005. Despite all the positives of the Kyoto Protocol, it had several drawbacks. One of the main drawbacks was that not all states adhered to it in good faith, in particular the United States never ratified the Protocol despite the fact that all states proclaimed the importance of combating climate change. Therefore, the Paris Agreement came to replace the Kyoto Protocol in 2015. Both documents are based on the principles of the "green economy" and aim to prevent climate change, but contain a number of differences, the main of which are:

- in the Paris Agreement, any sanctions for greenhouse emissions were canceled and each country determined for itself the amount of emission reductions. Thanks to this approach, more than 160 countries have joined the new agreement, some of which have not previously assumed commitments to reduce emissions;

- the Kyoto Protocol allows cross-border trading in quotas. This practice gave rise to opacity in the national accounting of greenhouse emissions and made it possible to implement corruption schemes, incl. in Ukraine.

- the Paris Agreement does not provide for interstate trading in quotas. Countries will be able to use market mechanisms to achieve their emission reduction targets, buying international carbon credits, which should reflect real emission reductions, and detailed rules for the operation of new market mechanisms should be approved at the next Conferences of the Parties to the UN Framework Convention on Climate Change. 
- the Paris Agreement provides for the technological and financial assistance by developed countries in emissions reduction to developing countries.

One of the most difficult issues of this agreement is the adoption of a new differentiation of countries into developed and developing countries in order to resolve the issue of who will provide financial and other assistance, and who will receive it. Traditional donors - the EU, USA, Canada and other developed countries do not give up their commitment and continue to be the leaders, providing and increasing funding to combat climate change. At the same time, among the countries that do not fall under the definition of "developed" - Saudi Arabia, South Korea, Singapore, there are those that are able to provide assistance, but do not want to do so. However, the Agreement states that they can provide assistance voluntarily [46].

Since the object of the study is Ukraine and France, based on the above, we note that France, as a result of the adoption of the Paris Agreement, is a country that provides financial assistance and Ukraine, in its turn, is a developing country and is applying for donor funds to fulfill the terms of this agreement.

For a deeper analysis of the level of such emissions as carbon dioxide, sulfur dioxide and nitric oxide into the environment, we select social, environmental and economic indicators from the groups of factors, which, in our opinion, have great influence on the level of harmful emissions and determine the main reasons for this influence, and opportunities to change them using the tools of the "green economy".

The criterion for assessing the closeness of the relationship between the studied pairs of emission indicators and the corresponding factors is the correlation coefficient. The influence assessment is carried out, assuming the possibility of the existence of not only a linear relationship, but also the possibility of various forms of nonlinear influence existence. For the study, there were chosen the following forms of non-linear connection: power, exponential, quadratic, inverse and logarithmic. Based on the analysis of the correlation coefficient value, there is selected the corresponding form of relationship, for which the value of the correlation coefficient is the largest (Tables 1-8).

Table 1. The results of analyzing the influence of the social factors set on harmful emissions in Ukraine.

\begin{tabular}{|c|c|c|}
\hline $\begin{array}{c}\text { Name of the } \\
\text { factor, } \\
\text { designation }\end{array}$ & $\begin{array}{c}\text { Form of the } \\
\text { detected } \\
\text { relationship }\end{array}$ & $\begin{array}{c}\text { The nature of the } \\
\text { identified } \\
\text { relationship }\end{array}$ \\
\hline $\begin{array}{c}\text { Human } \\
\text { Index, } \mathrm{X} 1\end{array}$ & $\begin{array}{c}\text { For } \mathrm{SO}_{2} \text { and } \mathrm{NOx} \\
- \text { not detected } \\
\text { for } \mathrm{CO}_{2}-\text { a square } \\
\text { relationship }\end{array}$ & $\begin{array}{c}\text { The factor } \\
\text { increases, } \\
\text { the indicators } \\
\text { decrease }\end{array}$ \\
\hline $\begin{array}{c}\text { Population } \\
\text { density, } \mathrm{X} 7\end{array}$ & $\begin{array}{c}\text { For } \mathrm{SO}_{2} \text { and } \mathrm{NOx} \\
\text { not detected } \\
\text { for } \mathrm{CO}_{2}-\text { an } \\
\text { inverse } \\
\text { relationship }\end{array}$ & $\begin{array}{c}\text { The factor } \\
\text { increases, the } \\
\text { indicators } \\
\text { increase }\end{array}$ \\
\hline
\end{tabular}

In our opinion, it is interesting to compare individual factors for the two countries, which have a different effect on the resulting indicator, in particular, the rent for the use of natural resources $\$$ in Ukraine increases, and at the same time, the level of $\mathrm{SO}_{2}$ and $\mathrm{NOx}$ emissions show an upward trend, and in France, in its turn, this factor also increases and the level of emissions decrease.

Table 2. The results of analyzing the influence of the social factors set on harmful emissions in France.

\begin{tabular}{|c|c|c|}
\hline $\begin{array}{c}\text { Name of the } \\
\text { factor, } \\
\text { designation }\end{array}$ & $\begin{array}{c}\text { Form of the } \\
\text { detected } \\
\text { relationship }\end{array}$ & $\begin{array}{c}\text { The nature of the } \\
\text { identified } \\
\text { relationship }\end{array}$ \\
\hline $\begin{array}{c}\text { Human } \\
\text { development } \\
\text { Index, X1 }\end{array}$ & Quadratic & $\begin{array}{c}\text { The factor increases, } \\
\text { the indicators } \\
\text { decrease }\end{array}$ \\
\hline $\begin{array}{c}\text { Population } \\
\text { density, X7 }\end{array}$ & Inverse & $\begin{array}{c}\text { The factor increases, } \\
\text { the indicators } \\
\text { decrease }\end{array}$ \\
\hline
\end{tabular}

Table 3. The results of analyzing the influence of the environmental factors set on harmful emissions in Ukraine.

\begin{tabular}{|c|c|c|}
\hline $\begin{array}{c}\text { Name of the factor, } \\
\text { designation }\end{array}$ & $\begin{array}{c}\text { Form of the } \\
\text { detected } \\
\text { relationship }\end{array}$ & $\begin{array}{c}\text { The nature of the } \\
\text { identified } \\
\text { relationship }\end{array}$ \\
\cline { 2 - 3 } Ukraine & Ukraine \\
\hline $\begin{array}{c}\text { Energy intensity of GDP } \\
\text { at constant purchasing } \\
\text { power parities (koe/\$ } \\
\text { 2015), X2 }\end{array}$ & $\begin{array}{c}\text { For } \mathrm{SO}_{2} \text { and } \mathrm{NO}_{\mathrm{x}} \\
\text { - not detected } \\
\left.\text { for } \mathrm{CO}_{2}-1 / \mathrm{X}\right) \\
\text { (a direct } \\
\text { relationship) }\end{array}$ & $\begin{array}{c}\text { The factor } \\
\text { increases, the } \\
\text { indicators } \\
\text { increase }\end{array}$ \\
\hline $\begin{array}{c}\text { Domestic consumption } \\
\text { of coal and lignite (Mt), } \\
\mathrm{X} 8\end{array}$ & Power & $\begin{array}{c}\text { The factor } \\
\text { increases, the } \\
\text { indicators } \\
\text { increase }\end{array}$ \\
\hline
\end{tabular}

Table 4. The results of analyzing the influence of the environmental factors set on harmful emissions in France.

\begin{tabular}{|c|c|c|}
\hline $\begin{array}{c}\text { Name of the factor, } \\
\text { designation }\end{array}$ & $\begin{array}{c}\text { Form of the } \\
\text { detected } \\
\text { relationship }\end{array}$ & $\begin{array}{c}\text { The nature of the } \\
\text { identified } \\
\text { relationship }\end{array}$ \\
\cline { 2 - 3 } France & France \\
\hline $\begin{array}{c}\text { Energy intensity of GDP } \\
\text { at constant purchasing } \\
\text { power parities (koe/\$ } \\
\text { 2015), X2 }\end{array}$ & Quadratic & $\begin{array}{c}\text { The factor } \\
\text { increases, the } \\
\text { indicators } \\
\text { decrease }\end{array}$ \\
\hline $\begin{array}{c}\text { Share of renewable } \\
\text { energy sources in } \\
\text { electricity production } \\
(\%), X 3\end{array}$ & Power & $\begin{array}{c}\text { The factor } \\
\text { increases, the } \\
\text { indicators } \\
\text { decrease }\end{array}$ \\
\hline $\begin{array}{c}\text { Domestic consumption } \\
\text { of coal and lignite (Mt), } \\
\text { X8 }\end{array}$ & Power & $\begin{array}{c}\text { The factor } \\
\text { increases, the } \\
\text { indicators } \\
\text { increase }\end{array}$ \\
\hline \multicolumn{2}{|c|}{} \\
\hline
\end{tabular}

This is due to the fact that the rent for the use of natural resources in Ukraine is not large and it does not induce to reduce emissions, and in France it is an effective tool as high rent encourages enterprises to reduce emissions in accordance with EU legislation.

The production factor (value added) in Ukraine and France tends to increase, which is a positive phenomenon, however, in France, emissions show a decrease, while in Ukraine they are growing. The reason for this situation may be the use of extensive factors of production, which give an increase in production volumes, raw materials 
prevail, services, tourist services, the use of intensive factors of production, and the latest technologies prevail.

Table 5. The results of analyzing the influence of the economic factors set on harmful emissions in Ukraine.

\begin{tabular}{|c|c|c|}
\hline $\begin{array}{c}\text { Name of the factor, } \\
\text { designation }\end{array}$ & $\begin{array}{l}\text { Form of the } \\
\text { detected } \\
\text { relationship }\end{array}$ & $\begin{array}{c}\text { The nature of } \\
\text { the identified } \\
\text { relationship }\end{array}$ \\
\hline $\begin{array}{c}\text { Rent for the use of } \\
\text { natural resources, } \$, X 4\end{array}$ & $\begin{array}{c}\text { A linear } \\
\text { relationship } \\
\text { (for } \mathrm{CO}_{2}-\text { not } \\
\text { detected) }\end{array}$ & $\begin{array}{l}\text { The factor } \\
\text { increases, the } \\
\text { indicators } \\
\text { increase }\end{array}$ \\
\hline $\begin{array}{l}\text { Production, value added } \\
\text { (current USD), } \\
\text { X5 }\end{array}$ & $\begin{array}{c}\text { Quadratic } \\
\text { (for } \mathrm{CO}_{2}-\text { not } \\
\text { detected) }\end{array}$ & $\begin{array}{l}\text { The factor } \\
\text { increases, the } \\
\text { indicators } \\
\text { increase }\end{array}$ \\
\hline $\begin{array}{c}\text { Foreign direct } \\
\text { investment, net inflows } \\
\text { (BoP, current USD), } \\
\text { X6 }\end{array}$ & $\begin{array}{c}\text { A linear } \\
\text { relationship } \\
\text { (for } \mathrm{CO}_{2}-\mathrm{a} \\
\text { low level of } \\
\text { relationship) }\end{array}$ & $\begin{array}{l}\text { The factor } \\
\text { increases, the } \\
\text { indicators } \\
\text { increase }\end{array}$ \\
\hline $\begin{array}{c}\text { Grain harvest (kg per } \\
\text { hectare), thousand, } \\
\text { X9 }\end{array}$ & $\begin{array}{c}\text { For } \mathrm{SO}_{2} \text { i NOx } \\
\text { - not detected, } \\
\text { (for } \mathrm{CO}_{2}-\mathrm{a} \\
\text { quadratic one) } \\
\end{array}$ & $\begin{array}{l}\text { The factor } \\
\text { increases, the } \\
\text { indicators } \\
\text { decrease }\end{array}$ \\
\hline $\begin{array}{c}\text { Total energy } \\
\text { consumption, X10 }\end{array}$ & Power & $\begin{array}{l}\text { The factor } \\
\text { increases, the } \\
\text { indicators } \\
\text { increase }\end{array}$ \\
\hline $\begin{array}{c}\text { Transport services ( } \% \text { of } \\
\text { commercial services } \\
\text { import), X12 }\end{array}$ & $\begin{array}{c}\text { For } \mathrm{NOx}-\mathrm{a} \\
\text { power } \\
\text { relationship, } \\
\text { for } \mathrm{SO}_{2}-\mathrm{a} \\
\text { logarithmic one, } \\
\text { for } \mathrm{CO}_{2}-\mathrm{a} \\
\text { quadratic one } \\
\end{array}$ & $\begin{array}{l}\text { The factor } \\
\text { increases, the } \\
\text { indicators } \\
\text { increase }\end{array}$ \\
\hline $\begin{array}{c}\text { Unemployment, total (\% } \\
\text { of total labor force) } \\
\text { (ILO modeled estimate), } \\
\text { X13 }\end{array}$ & $\begin{array}{c}\text { Inverse } \\
\text { (for } \mathrm{CO}_{2}-\text { not } \\
\text { detected) }\end{array}$ & $\begin{array}{l}\text { The factor } \\
\text { increases, the } \\
\text { indicators } \\
\text { decrease }\end{array}$ \\
\hline $\begin{array}{c}\text { Exports of ores and } \\
\text { metals ( } \% \text { of } \\
\text { merchandise exports), } \\
\text { X14 }\end{array}$ & $\begin{array}{l}\text { Logarithmic } \\
\text { (a low level of } \\
\text { relationship) }\end{array}$ & $\begin{array}{l}\text { The factor } \\
\text { increases, the } \\
\text { indicators } \\
\text { decrease }\end{array}$ \\
\hline
\end{tabular}

With an increase in research and development costs, emissions in Ukraine increase, while in France they decrease. This gives grounds to assert that money is spent on the wrong developments in Ukraine, and in France, intellectual developments are sufficiently introduced at enterprises that ensure emissions reductions.

In accordance with the obtained calculations, we will rank the factors within each group according to the values of the correlation coefficient (Tables 9-10): 1 - the highest level of influence, 3 - the lowest level of influence (for social, environmental, scientific and intellectual factors), 1 - the highest level of influence, 8 - the lowest level of influence (for economic factors).

Summing up, we can say that for all groups of factors for both countries, it is worth highlighting a number of effective tools that make it possible to reduce emissions by decreasing the negative influence of individual factors, as evidenced to a greater extent by statistics on the main indicators of France. In its turn, Ukraine has the opportunity to study the experience of France and other countries, in order to implement effective socio-economic and environmental policies, measures in the context of reducing emissions in various fields of activity, thereby observing the foundations of a green economy.

Table 6. The results of analyzing the influence of the economic factors set on harmful emissions in France.

\begin{tabular}{|c|c|c|}
\hline $\begin{array}{c}\text { Name of the factor, } \\
\text { designation }\end{array}$ & $\begin{array}{l}\text { Form of the } \\
\text { detected } \\
\text { relationship }\end{array}$ & $\begin{array}{l}\text { The nature of } \\
\text { the identified } \\
\text { relationship }\end{array}$ \\
\hline $\begin{array}{c}\text { Rent for the use of } \\
\text { natural resources, } \$, X 4\end{array}$ & Quadratic & $\begin{array}{l}\text { The factor } \\
\text { increases, the } \\
\text { indicators } \\
\text { decrease }\end{array}$ \\
\hline $\begin{array}{l}\text { Production, value added } \\
\text { (current USD), X5 }\end{array}$ & $\begin{array}{c}\text { Inverse (for } \mathrm{CO}_{2} \\
\text { - a low level of } \\
\text { relationship) }\end{array}$ & $\begin{array}{l}\text { The factor } \\
\text { increases, the } \\
\text { indicators } \\
\text { decrease }\end{array}$ \\
\hline $\begin{array}{c}\text { Foreign direct } \\
\text { investment, net inflows } \\
\text { (BoP, current USD), X6 }\end{array}$ & $\begin{array}{c}\text { Power (low level } \\
\text { of relationship) }\end{array}$ & $\begin{array}{l}\text { The factor } \\
\text { increases, the } \\
\text { indicators } \\
\text { increase }\end{array}$ \\
\hline $\begin{array}{l}\text { Grain harvest (kg per } \\
\text { hectare), thousand, X9 }\end{array}$ & Not detected & \\
\hline $\begin{array}{c}\text { Total energy } \\
\text { consumption, X10 }\end{array}$ & Power & $\begin{array}{l}\text { The factor } \\
\text { increases, the } \\
\text { indicators } \\
\text { increase }\end{array}$ \\
\hline $\begin{array}{c}\text { Transport services (\% of } \\
\text { commercial services } \\
\text { exports), X11 }\end{array}$ & Power & $\begin{array}{c}\text { The factor } \\
\text { increases, the } \\
\text { indicators } \\
\text { increase }\end{array}$ \\
\hline $\begin{array}{c}\text { Transport services ( } \% \text { of } \\
\text { commercial services } \\
\text { import), X12 }\end{array}$ & Quadratic & $\begin{array}{l}\text { The factor } \\
\text { increases, the } \\
\text { indicators } \\
\text { increase }\end{array}$ \\
\hline $\begin{array}{c}\text { Unemployment, total (\% } \\
\text { of total labor force) } \\
\text { (ILO modeled estimate), } \\
\text { X13 }\end{array}$ & $\begin{array}{l}\text { Exponential (a } \\
\text { low level of } \\
\text { relationship) }\end{array}$ & $\begin{array}{c}\text { The factor } \\
\text { increases, the } \\
\text { indicators } \\
\text { increase }\end{array}$ \\
\hline $\begin{array}{c}\text { Exports of ores and } \\
\text { metals (\% of } \\
\text { merchandise exports), } \\
\text { X14 }\end{array}$ & $\begin{array}{l}\text { Inverse (a low } \\
\text { level of } \\
\text { relationship) }\end{array}$ & $\begin{array}{l}\text { The factor } \\
\text { increases, the } \\
\text { indicators } \\
\text { decrease }\end{array}$ \\
\hline
\end{tabular}

Table 7. The results of analyzing the influence of the scientific and intellectual factors set on harmful emissions in Ukraine.

\begin{tabular}{|c|c|c|}
\hline $\begin{array}{c}\text { Name of the factor, } \\
\text { designation }\end{array}$ & $\begin{array}{c}\text { Form of the } \\
\text { detected } \\
\text { relationship }\end{array}$ & $\begin{array}{c}\text { The nature of the } \\
\text { identified } \\
\text { relationship }\end{array}$ \\
\hline $\begin{array}{c}\text { Property Fees, } \\
\text { Payments (BoP, } \\
\text { Current US Dollars) } \\
\text { Research and } \\
\text { development costs \$, } \\
\text { X15 }\end{array}$ & $\begin{array}{c}\text { Quadratic (for } \mathrm{CO}_{2} \\
\text { - not detected) }\end{array}$ & $\begin{array}{c}\text { The factor } \\
\text { increases, the } \\
\text { indicators increase }\end{array}$ \\
\hline $\begin{array}{c}\text { Research and } \\
\text { development costs, } \\
\$, \mathrm{X} 16\end{array}$ & $\begin{array}{c}\text { A linear relationship } \\
\text { (for } \mathrm{CO}_{2}-\text { not } \\
\text { detected) }\end{array}$ & $\begin{array}{c}\text { The factor } \\
\text { increases, the } \\
\text { indicators increase }\end{array}$ \\
\hline $\begin{array}{c}\text { Patent applications, } \\
\text { residents, X17 }\end{array}$ & $\begin{array}{c}\text { Logarithmic for } \\
\mathrm{CO}_{2} \text { (a low level of } \\
\text { relationship) }\end{array}$ & $\begin{array}{c}\text { The factor } \\
\text { increases, the } \\
\text { indicators increase }\end{array}$ \\
\hline
\end{tabular}

Summarizing the reasons that lead to changes in the factors affecting the volumes of emissions, it should be noted that they take place at all levels, namely at the levels 
of cooperation between different countries, unions (global), state, local and individual. In particular:

1. Key global initiatives that demonstrate attempts to find a global consensus around the increasing importance of the environmental factor in the activities of international organizations, institutional investors and TNCs, as well as in the politics of the countries of the world, reflected in the foundations of the transition to a "green" economy.

Table 8. The results of analyzing the influence of the scientific and intellectual factors set on harmful emissions in France.

\begin{tabular}{|c|c|c|}
\hline $\begin{array}{c}\text { Name of the factor, } \\
\text { designation }\end{array}$ & $\begin{array}{c}\text { Form of the } \\
\text { detected } \\
\text { relationship }\end{array}$ & $\begin{array}{c}\text { The nature of } \\
\text { the identified } \\
\text { relationship }\end{array}$ \\
\hline $\begin{array}{c}\text { Property Fees, Payments } \\
\text { (BoP, Current US } \\
\begin{array}{c}\text { Dollars), Research and } \\
\text { development costs \$, } \\
\text { X15 }\end{array}\end{array}$ & $\begin{array}{c}\text { For } \mathrm{NO}_{\text {and }} \mathrm{SO}_{2} \\
\text { - logarithmic } \\
\text { relationship. } \\
\text { For } \mathrm{CO}_{2} \text { - a linear } \\
\text { relationship. }\end{array}$ & $\begin{array}{c}\text { The factor } \\
\text { increases, the } \\
\text { indicators } \\
\text { decrease }\end{array}$ \\
\hline $\begin{array}{c}\text { Research and } \\
\text { development costs, \$, } \\
\text { X16 }\end{array}$ & $\begin{array}{c}\text { A linear } \\
\text { relationship }\end{array}$ & $\begin{array}{c}\text { The factor } \\
\text { increases, the } \\
\text { indicators } \\
\text { decrease }\end{array}$ \\
\hline $\begin{array}{c}\text { Patent applications, } \\
\text { residents, }\end{array}$ & $\begin{array}{c}\text { Inverse (for } \mathrm{CO}_{2}- \\
0,46 \text { a low level of } \\
\text { relationship) }\end{array}$ & $\begin{array}{c}\text { The factor } \\
\text { increases, the } \\
\text { indicators } \\
\text { decrease }\end{array}$ \\
\hline
\end{tabular}

Table 9. Ranking of factors by the value of the correlation coefficient (France).

\begin{tabular}{|c|c|c|c|}
\hline Factor rank & $\mathrm{CO}_{2}$ & $\mathbf{S O}_{2}$ & Nox \\
\hline \multicolumn{4}{|c|}{ Social } \\
\hline 1 & $\mathrm{X} 7$ & $\mathrm{X} 7$ & $\mathrm{X} 7$ \\
\hline 2 & $\mathrm{X} 1$ & \begin{tabular}{|l|}
$\mathrm{X} 1$ \\
\end{tabular} & $\mathrm{X} 1$ \\
\hline 3 & X9 & \begin{tabular}{|l|l|}
$\mathrm{X} 9$ \\
\end{tabular} & X9 \\
\hline \multicolumn{4}{|c|}{ Economic } \\
\hline 1 & $\mathrm{X} 12$ & $\mathrm{X} 12$ & $\mathrm{X} 12$ \\
\hline 2 & $\mathrm{X} 10$ & $\mathrm{X} 4$ & $\mathrm{X} 4$ \\
\hline 3 & $\mathrm{X} 4$ & $\mathrm{X} 10$ & $\mathrm{X} 10$ \\
\hline 4 & $\mathrm{X} 11$ & $\mathrm{X} 5$ & $\mathrm{X} 5$ \\
\hline 5 & X6 & $\mathrm{X} 11$ & $\mathrm{X} 11$ \\
\hline 6 & $\mathrm{X} 5$ & $\mathrm{X} 14$ & $\mathrm{X} 6$ \\
\hline 7 & $\mathrm{X} 13$ & X13 & $\mathrm{X} 14$ \\
\hline 8 & $\mathrm{X} 14$ & X6 & $\mathrm{X} 13$ \\
\hline \multicolumn{4}{|c|}{ Environmental } \\
\hline 1 & $\mathrm{X} 2$ & $\mathrm{X} 2$ & $\mathrm{X} 2$ \\
\hline 2 & $\mathrm{X} 8$ & X8 & $\mathrm{X} 8$ \\
\hline 3 & X3 & X3 & X3 \\
\hline \multicolumn{4}{|c|}{ Scientific and intellectual } \\
\hline 1 & $\mathrm{X} 15$ & $\mathrm{X} 15$ & $\mathrm{X} 15$ \\
\hline 2 & $\mathrm{X} 16$ & $\mathrm{X} 16$ & $\mathrm{X} 16$ \\
\hline 3 & X17 & $\mathrm{X} 17$ & $\mathrm{X} 17$ \\
\hline
\end{tabular}

These initiatives are, first of all, declared in the documents as the goals that must be achieved by a specific time (the 2030 Agenda for Sustainable Development, the Sustainable Development Goals and the Paris Agreement), at the level of the European Union, the European climate law. Responsibilities for the implementation of the measures in these documents are assigned directly to the governments of each country that ratified these regulations. Therefore, both in Ukraine and in France, the following documents were adopted on their basis at the state level. The political and legislative framework for the climate policy in Ukraine is provided by the Law "On the Basics of Monitoring, Reporting and Verification of Greenhouse Gas Emissions", Ukraine 2050 Low Emission Development Strategy (LEDS), the CONCEPT of State Climate Change Policy Implementation until 2030. In France, the main regulatory documents on the implementation of international agreements are the Law on Energy Transition for Green Growth (LTECV), the National Adaptation Plan for Climate Change, and the National Low Carbon Strategy. That is, the legislative base has been formed, but there are a number of shortcomings. In particular, it is necessary for Ukraine to create an integral and effective regulatory framework for a system of regulating harmful emissions, fully adapted to global international agreements. The priority here should be a set of legislative actions that are relevant to improve taxation of emissions, as well as the use of funds received from tax revenues for emissions. After reviewing the French regulations, a minor flaw can be considered the difficulty of understanding them, as they cover different areas together with very detailed provisions for implementation at different levels and with different time frames.

Table 10. Ranking of factors by the value of the correlation coefficient (Ukraine).

\begin{tabular}{|c|c|c|c|}
\hline Factor rank & $\mathrm{CO}_{2}$ & $\mathbf{S O}_{2}$ & Nox \\
\hline \multicolumn{4}{|c|}{\begin{tabular}{|c|} 
Social \\
\end{tabular}} \\
\hline 1 & X9 & X9 & X9 \\
\hline 2 & X7 & X7 & $\mathrm{X} 7$ \\
\hline 3 & $\mathrm{X} 1$ & $\mathrm{X} 1$ & $\mathrm{X} 1$ \\
\hline \multicolumn{4}{|c|}{ Economic } \\
\hline 1 & $\mathrm{X} 10$ & $\mathrm{X} 4$ & $\mathrm{X} 4$ \\
\hline 2 & $\mathrm{X} 12$ & $\mathrm{X} 12$ & $\mathrm{X} 5$ \\
\hline 3 & X6 & $\mathrm{X} 5$ & $\mathrm{X} 12$ \\
\hline 4 & $\mathrm{X} 10$ & $\mathrm{X} 13$ & $\mathrm{X} 6$ \\
\hline 5 & $\mathrm{X} 13$ & $\mathrm{X} 6$ & $\mathrm{X} 13$ \\
\hline 6 & $\mathrm{X} 14$ & $\mathrm{X} 10$ & $\mathrm{X} 10$ \\
\hline 7 & $\mathrm{X} 4$ & $\mathrm{X} 14$ & $\mathrm{X} 11$ \\
\hline 8 & $\mathrm{X} 5$ & $\mathrm{X} 11$ & $\mathrm{X} 14$ \\
\hline \multicolumn{4}{|c|}{ Environmental } \\
\hline 1 & $\mathrm{X} 8$ & $\mathrm{X} 8$ & $\mathrm{X} 8$ \\
\hline 2 & $\mathrm{X} 2$ & $\mathrm{X} 3$ & $\mathrm{X} 3$ \\
\hline 3 & $\mathrm{X} 3$ & $\mathrm{X} 2$ & $\mathrm{X} 2$ \\
\hline \multicolumn{4}{|c|}{ Scientific and intellectual } \\
\hline 1 & $\mathrm{X} 17$ & $\mathrm{X} 16$ & $\mathrm{X} 16$ \\
\hline 2 & $\mathrm{X} 16$ & $\mathrm{X} 15$ & $\mathrm{X} 15$ \\
\hline 3 & $\mathrm{X} 15$ & $\mathrm{X} 17$ & $\mathrm{X} 17$ \\
\hline
\end{tabular}

2. The next tool that can ensure the reduction of emissions and funding budgets for improvement of environmental situation and promotion of green business development is the application of effective state fiscal policy. Today in Ukraine, rates for harmful emissions remain one of the lowest in Europe (as an example, $0.33 \%$ per ton of $\mathrm{CO}_{2}$ emissions in 2019), while in France they are one of the highest and grow from year to year $(€ 35$ per ton of $\mathrm{CO}_{2}$ emissions in 2019). In addition, the list of environmental taxes has 20 items in France, and according to Eurostat, they are classified into the following categories: energy, transport, pollution, subsoil. In Ukraine, however, there is no clear classification of the 
environmental tax to the object of taxation. Also, revenues from the environmental tax are spent opaquely and ineffectively. Companies that pollute the environment have been paying fees since 2011, but most of environmental problems still remain unsolved. In addition, low rates of environmental taxes do not stimulate business entities to invest in environmental protection measures. In France, however, high environmental tax rates are often the cause of strikes in the country. One of the reasons is high fuel rates. However, not all funds are used for environmental activities, and most of them are directed to pay for the budget deficit (from 34 billion euros that the French government received from a fuel tax in 2018, 7.2 billion euros were allocated for environmental activities).

3. Studies show that environmental taxation of European countries has proven its effectiveness in the implementation of environmental policy. This contributed to the rapid production of innovative technologies in environmental protection measures and the reduction of harmful emissions [46].

4. Renewable energy sources help solve sustainable development challenges by reducing air, water and soil pollution [47]. It is the increase in the use of renewable energy that is one of the priority directions for the implementation of the countries state policy in the field of energy efficiency. In France, utilities use the Energy Efficiency Certification Scheme (also known as "white certificates") to meet their energy reduction targets, which in turn include performing energy audits, government granting targeted subsidies for energy efficient equipment, using renewable energy sources and the like. The white certificate scheme started in France back in 2006. Improving energy savings in the residential sector, which is one of the largest consumers of energy resources, is also the main task of the climate and energy policy of each country. In France, an important part of the country's Policy Strategy for Decarbonizing the Buildings Sector is a tax credit scheme for costs associated with energy efficient renovation works, the so-called The Energy Transition Tax Credit (CITE). In Ukraine, the instruments of state support for the population in the sphere of energy efficiency are two nationwide programs to improve the energy efficiency of the housing stock: the so-called "Warm credits", handled by the State Agency on Energy Efficiency and Energy Saving of Ukraine "SAEE", and the Energy Efficiency Fund program "Energodim".

5. One of the most important roles in the development of innovative processes in the energy sector is played by the governments of countries, which often fund high-risk research, as well as new low-carbon technologies, which, as a rule, are not cheap and are characterized by a plurality of market prices. One of the most effective ways to assess the implementation of clean energy technologies is to assess the level of public investment in energy R\&D and demonstration activities (R\&D and DA) and identify the relationship between these investments and technology development. The total amount of state funding for energy R\&D and DA in 2018 in France is 1.526 million euros, which puts it in first place among the EU countries, in Ukraine this information is absent. The assets received are often intangible, the returns are uncertain, and the investment in innovation is not always easy and quick to return. This is where government support is an important resource for long-term finance. Policy instruments can be used to ensure access to financing risky projects. As a result, many high-risk private sector innovations are based on early stages of publicly funded research and programs.

\section{Conclusions}

Based on the analysis, there have been identified effective legislative, organizational and management tools that will contribute to reducing emissions for developing countries:

- formation, bringing up to European standards of the legal framework on regulation, management and control in the field of the environment;

- maintaining an effective fiscal policy in matters of rent payments, environmental taxes and fines;

- intensive use of "green investment" instruments, namely "green" bonds;

- reduction in energy consumption due to the use of certification schemes for the result of energy conservation, the so-called "white certificates";

- an increase in the amount of public investment in energy R\&D and demonstration activities;

The research results allow in the future building multivariate econometric models to assess the complex influence of such factors on emissions and formulating recommendations for improving social, environmental and economic policies to ensure the reduction of harmful emissions.

\section{References}

1. Danish, M.A. Baloch, N. Mahmood, J.W. Zhang, Effect of natural resources, renewable energy and economic development on $\mathrm{CO} 2$ emissions in BRICS countries, Science of The Total Environment 678, 632638 (2019). doi: 10.1016/j.scitotenv.2019.05.028.

2. D. Balsalobre-Lorente, M. Shahbaz, D. Roubaud, and S. Farhani, How Economic Growth, Renewable Electricity and Natural Resources Contribute to CO2 Emissions?, Energy Policy 113, 356-367 (2018). doi:10.1016/j.enpol.2017.10.050.

3. U. Soytas, R. Sari, and B. T. Ewing, Energy Consumption, Income, and Carbon Emissions in the United States, Ecological Economics 62, 482-489 (2007). doi:10.1016/j.ecolecon.2006.07.009.

4. S. S. Sharma, Determinants of Carbon Dioxide Emissions: Empirical Evidence from 69 Countries, Applied Energy 88, 376-382 (2011). doi:10.1016/j.apenergy.2010.07.022.

5. M. Song, R. Fisher, and Y. Kwoh, Technological Challenges of Green Innovation and Sustainable Resource Management with Large Scale Data, Technological Forecasting and Social Change 144, 361-368 (2019). doi:10.1016/j.techfore.2018.07.055.

6. W. Gu, X. Zhao, X. Yan, C. Wang, and Q. Li, Energy Technological Progress, Energy Consumption, and CO2 Emissions: Empirical Evidence from China, 
Journal of Cleaner Production 236, 1-52 (2019). doi:10.1016/j.jclepro.2019.117666.

7. A. Zaporozhets, V. Babak, V. Isaienko, and K. Babikova, Analysis of the Air Pollution Monitoring System in Ukraine, in Systems, Decision and Control in Energy I, edited by V. Babak, V. Isaienko, and A. Zaporozhets, (Springer International Publishing, Cham, 2020). doi:10.1007/978-3-030-48583-2_6.

8. O. Popov, A. Iatsyshyn, V. Kovach, V. Artemchuk, I. Kameneva, D. Taraduda, V. Sobyna, D. Sokolov, M. Dement, and T. Yatsyshyn, Risk Assessment for the Population of Kyiv, Ukraine as a Result of Atmospheric Air Pollution, Journal of Health and Pollution 10, 200303 (2020). doi:10.5696/2156-961410.25 .

9. K. Bashir Shaban, A. Kadri, and E. Rezk, Urban Air Pollution Monitoring System With Forecasting Models, IEEE Sensors J. 16, 2598-2606 (2016). doi:10.1109/JSEN.2016.2514378.

10. A. Kuchansky, A. Biloshchytskyi, Y. Andrashko, V. Vatskel, S. Biloshchytska, O. Danchenko, and I. Vatskel, Combined Models for Forecasting the Air Pollution Level in Infocommunication Systems for the Environment State Monitoring, in 2018 IEEE 4th International Symposium on Wireless Systems within the International Conferences on Intelligent Data Acquisition and Advanced Computing Systems (IDAACS-SWS) (IEEE, Lviv, 2018), 125-130. doi:125-130.10.1109/IDAACS-SWS.2018.8525608.

11. O. Popov, A. Iatsyshyn, V. Kovach, V. Artemchuk, D. Taraduda, V. Sobyna, D. Sokolov, M. Dement, and T. Yatsyshyn Conceptual Approaches for Development of Informational and Analytical Expert System for Assessing the NPP impact on the Environment. Nuclear and Radiation Safety 3(79), 56-65 (2018). doi:10.32918/nrs.2018.3(79).09.

12. A. Iatsyshyn, A. Iatsyshyn, V. Artemchuk, I. Kameneva, V. Kovach, and O. Popov, Software Tools for Tasks of Sustainable Development of Environmental Problems: Peculiarities of Programming and Implementation in the Specialists' Preparation, E3S Web Conf. 166, 01001 (2020). doi:10.1051/e3sconf/202016601001.

13. A. Zaporozhets, Overview of Quadrocopters for Energy and Ecological Monitoring, in Systems, Decision and Control in Energy I, edited by V. Babak, V. Isaienko, and A. Zaporozhets, (Springer International Publishing, Cham, 2020). doi:10.1007/978-3-030-48583-2_2.

14. A. Agarwal, V. Shukla, R. Singh, A. Gehlot, and V. Garg, Design and Development of Air and Water Pollution Quality Monitoring Using IoT and Quadcopter, in Intelligent Communication, Control and Devices, edited by R. Singh, S. Choudhury, and A. Gehlot, (Springer Singapore, Singapore, 2018). doi: 10.1007/978-981-10-5903-2_49.

15. N. Pobihun, Y. Korobeinykova, O. Pobihun, and I. Iuras, Ecological and Monitoring Studies of Oil Production Territories and Possibility of Their Use in
Recreation, in Monitoring 2019 (European Association of Geoscientists \& Engineers, Kyiv, Ukraine, 2019), 1-5 (2019). doi:10.3997/2214-4609. 201903183.

16. L.E. Shkitsa, T.M. Yatsyshyn, A.A. Popov, and V.A. Artemchuk. The development of mathematical tools for ecological safe of atmosfere on the drilling well area, Neftyanoe khozyaystvo 11, 136-140, (2013).

17. J. Fairburn, S. A. Schüle, S. Dreger, L. Karla Hilz, and G. Bolte, Social Inequalities in Exposure to Ambient Air Pollution: A Systematic Review in the WHO European Region, IJERPH 16, 3127 (2019). doi:10.3390/ijerph16173127.

18. O. Kubatko and O. Kubatko, Economic Estimations of Air Pollution Health Nexus, Environ Dev Sustain 21, 1507-1517 (2019). doi: 10.1007/s10668-018-0252-6.

19. O. Popov, A. Iatsyshyn, V. Kovach, V. Artemchuk, D. Taraduda, V. Sobyna, D. Sokolov, M. Dement, V. Hurkovskyi, K. Nikolaiev, T. Yatsyshyn, and D. Dimitriieva, Physical Features of Pollutants Spread in the Air During the Emergency at NPPs, Nucl. and Rad. Safe. 4(84), 88-98 (2019). doi:10.32918/ nrs.2019.4(84).11.

20. O. Popov, A. Iatsyshyn, V. Kovach, V. Artemchuk, D. Taraduda, V. Sobyna, D. Sokolov, M. Dement, T. Yatsyshyn, and I. Matvieieva, Analysis of Possible Causes of NPP Emergencies to Minimize Risk of Their Occurrence, Nucl. and Rad. Safe. 1(81), 75-80 (2019). doi:10.32918/nrs.2019.1(81).13.

21. A.O. Zaporozhets, Research of the Process of Fuel Combustion in Boilers, in Control of Fuel Combustion in Boilers (Springer International Publishing, Cham, 2020). doi:10.1007/978-3-030-46299-4_2.

22. A. Zaporozhets, Analysis of Control System of Fuel Combustion in Boilers with Oxygen Sensor, Period. Polytech. Mech. Eng. 63, 241-248 (2019). doi:10.3311/PPme.12572.

23. T. Yatsyshyn, L. Shkitsa, O. Popov, and M. Liakh, Development of Mathematical Models of Gas Leakage and Its Propagation in Atmospheric Air at an Emergency Gas Well Gushing, EEJET 5, 49-59 (2019). doi:10.15587/1729-4061.2019.179097.

24. S.M. Cabaneros, J.K. Calautit, B.R. Hughes. A review of artificial neural network models for ambient air pollution prediction. Environmental Modelling \& Software, 119, 285-304. (2019). doi: 10.1016/j.envsoft.2019.06.014.

25. C. Song, G. Huang, B. Zhang, B. Yin, and H. Lu, Modeling Air Pollution Transmission Behavior as Complex Network and Mining Key Monitoring Station, IEEE Access 7, 121245-121254 (2019). doi: 10.1109/ACCESS.2019.2936613.

26. Y. Kyrylenko, I. Kameneva, O. Popov, A. Iatsyshyn, V. Artemchuk, and V. Kovach, Source Term Modelling for Event with Liquid Radioactive Materials Spill, in Systems, Decision and Control in Energy I, edited by V. Babak, V. Isaienko, and A. Zaporozhets, (Springer International Publishing, Cham, 2020). doi:10.1007/978-3-030-48583-2_17. 
27. V. Gurieiev, Yu. Kutsan, A. Iatsyshyn, A. Iatsyshyn, V. Kovach, E. Lysenko, V. Artemchuk, O. Popov, Simulating Systems for Advanced Training and Professional Development of Energy Specialists in Power Sector, in CEUR Workshop Proceedings, vol. 2732, (2020), pp. 693-708. http://ceur-ws.org/Vol2732/20200693.pdf Accessed 25 Nov 2020.

28. L. Shkitsa, T. Yatsyshyn, M. Lyakh, O. Sydorenko, Innovative approaches to the formation of environmental safety at the objects of oil and gas production. IOP Con f. Ser.: Mater. Sci. Eng. 749, 012009 (2020). doi:10.1088/1757-899X/749/1/ 012009.

29. T. Yatsyshyn, N. Glibovytska, L. Skitsa, M. Liakh, S. Kachala, in Studies in Systems, Decision and Control Systems, ed. by V. Babak, V. Isaienko, A. Zaporozhets. Investigation of Biotechnogenic System Formed by Long-Term Impact of Oil Extraction Objects, (Springer, Cham, 2020). doi:10.1007/978-3030-48583-2_11.

30. Y.S. Korobeinykova, I.I. Iuras. Selected aspects of socio-economic and ecological consequences of the tourism development in the Ukrainian Carpathians. Prace I Studia Geograficzne. 62, 55-73. (2017). https://wgsr.uw.edu.pl/pisg/wp-content/uploads/2020 / 09/3_YK_II_16-12-2017.pdf.

31. L. Skitsa, T. Yatsyshyn, M. Liakh, O. Sydorenko, Ways to improve safety of a pumping-circulatory system of a drilling rig. Min. Miner. Depos. 12(3), 7179 (2018). doi:10.15407/mining12.03.071.

32. T. Yatsyshyn, Y. Mykhailiuk, M. Liakh, I. Mykhailiuk, V. Savyk, I. Dobrovolsky. Establishing the dependence of pollutant concentration on operational conditions at facilities of an oil and gas complex. EEJET. 2/10(92), 56-63 (2018). doi:10.15587/1729-4061.2018.126624.

33. M.L. Myrontsov, Electrometry Effective Inverse Problem Solving Method, in Geoinformatics: Theoretical and Applied Aspects 2020 (European Association of Geoscientists \& Engineers, Kyiv, Ukraine, 2020), 1-5. doi:10.3997/2214-4609.2020 geo090.

34. O. Korchenko, V. Pohrebennyk, D. Kreta, V. Klymenko, Y. Anpilova. GIS and remote sensing as important tools for assessment of environmental pollution, in Extended Abstracts of 19th International Multidisciplinary Scientific GeoConference SGEM, Sofia, 9 - 11 December, 2019, vol. 19 (2.1), pp. 297304.

35. M.L. Myrontsov. The method to research equivalent solutions zones for inverse problem of well logging electrometry, in Proceedings of the XIII International Scientific Conference "Monitoring of Geological Processes and Ecological Condition of the Environment", 2019, 1-5 (2019). doi:10.3997/22144609.201903217.

36. O. Trofymchuk, Y. Yakovliev, V. Klymenko, Y. Anpilova. Geomodeling and monitoring of pollution of waters and soils by the Earth remote sensing, in
Extended Abstracts of 19th International Multidisciplinary Scientific GeoConference SGEM, Sofia, 9-11 December, 2019, vol. 19 (1.4), pp. 197 204.

37. M. Myrontsov. The method to solve the inverse problem of lateral logging sounding and lateral logging, in Monitoring 2019, 2019 (European Association of Geoscientists \& Engineers, Kyiv, Ukraine, 2019), 1-5. doi:10.3997/2214-4609. 201903244.

38. M.L. Myrontsov, Multi-Probe Hardware for Electrometry of Oil and Gas Wells, Sci. Innov. 14(3), 51-56 (2018). doi: 10.15407/scine14.03.051.

39. O. Mandryk, N. Moskalchuk L. Arkhypova, M. Prykhodko, and O. Pobigun. Prospects of environmentally safe use of renewable energy sources in the sustainable tourism development of the Carpathian region of Ukraine. E3S Web Conf. 166, 04005 (2020). doi:10.1051/e3sconf/202016604005.

40. O.M. Mandryk, N.R. Moskalchuk, L.M. Arkhypova, M.M. Pryhodko, and O.V. Pobigun, Research quantitative indicators of the potential of solar energy in the Carpathian region of Ukraine. IOP Conf. Ser.: Mater. Sci. Eng. 749, 012033 (2020). doi:10.1088/1757-899X/749/1/012033.

41. O. Savko, I. Melnychuk, I. Hobyr, and N. Havadzyn, Evaluation of the environmental taxation effectiveness in the field of oil and gas production. Procedia Environ. Sci. Eng. Manag. 6(4), 607-617 (2019). http://www.procedia-esem.eu/pdf/issues/ 2019/no4/69_Savko_19.pdf. Accessed 30 Nov 2020.

42. I. Iuras, P. Raiter, Y. Korobeinykova, and L. Poberezhna, Methodology of Actors Analysis and Modeling of the Amounts of Solid Municipal Waste Generation within Tourist Destinations. EQ. 31(2), 63-69 (2020). doi: 10.12775/EQ.2020.014.

43. I. Murava and Y. Korobeinykova, The analysis of the waste problem in tourist destinations on the example of carpathian region in ukraine, J. Ecol. Eng. 17, 4351 (2016). doi: 10.12911/22998993/62285.

44. A. Iatsyshyn, A. Iatsyshyn, V. Kovach, I. Zinovieva, V. Artemchuk, O. Popov, O. Cholyshkina, O. Radchenko, O. Radchenko, A. Turevych. Application of Open and Specialized Geoinformation Systems for Computer Modelling Studying by Students and $\mathrm{PhD}$ Students, in CEUR Workshop Proceedings, vol. 2732, (2020), pp.893-908, http://ceur-ws.org/Vol2732/20200893.pdf. Accessed 25 Nov 2020.

45. S. Kis, L. Mosora, Y. Mosora, O. Yatsiuk, G. Malynovska, S. Pobihun. Personnel Certification as a Necessary Condition for Enterprise' Staff Development, Management Systems in Production Engineering 28(2), 121-126 (2020). doi:10.2478/mspe-2020-0018.

46. S. Mikhailets. Green money in French: how they work. (Delo.Ua, 2017). http://delo.ua/business/zeleni -groshi-po-francuzki-jak-voni-pracjujut-335115/. Accessed 05 Oct. 2017. 
47. O.M. Mandryk, L.M. Arkhypova, O.V. Pobigun, and O.R. Maniuk, Renewable Energy Sources for Sustainable Tourism in the Carpathian Region, IOP Conf. Ser.: Mater. Sci. Eng. 144, 012007 (2016). doi: 10.1088/1757-899X/144/1/012007. 